\title{
AN ANNOTATED TRANSLATION OF A NOVEL ENTITLED THE GREAT PATRIOTIC WAR OF THE SOVIET UNION
}

\author{
I Nyoman Adnyana ${ }^{1}$ \\ ${ }^{1}$ Program Studi Ilmu Bahasa dan Sastra, Universitas Nasional \\ email: nyoman1355@gmail.com
}

Korespondensi : nyoman1355@gmail.com

\begin{abstract}
Abstrak
Penelitian ini tentang terjemahan beranotasi dengan objek sebuah novel berjudul The Great Patriotic War of the Soviet Union yang ditulis oleh Joseph Stalin. Permasalahan dalam penelitian ini antara lain: (1) Apa kesulitan yang dihadapi oleh peneliti dalam menerjemahkan teks suatu bahasa? dan (2) Bagaimana kesulitan-kesulitan tersebut diselesaikan dalam terjemahan? Tujuan dari penelitian ini adalah: (1) Untuk mengidentifikasi kesulitan yang dihadapi oleh penerjemah dalam menerjemahkan teks bahasa sumber; dan (2) Bagaimana kesulitan tersebut dipecahkan yang mencakup strategi dalam menerjemahkan teks bahasa sumber. Dalam melakukan terjemahan beranotasi ini, peneliti menggunakan metode introspektif dan retrospektif. Peneliti menganalisis 25 anotasi masalah dari 100 data yang terkait dengan leksikon, struktur gramatikal, situasi komunikasi, dan konteks kultural, dan mengungkapkan bahwa ada 17 leksikon, 7 struktur gramatikal, dan 1 situasi komunikasi. Kesulitan-kesulitan yang, pada saat yang sama, telah menjadi masalah yang dianalisis untuk mencapai solusi sesuai dengan strategi terjemahan yang relevan dan teori terjemahan, yaitu: terjemahan deskriptif, naturalisasi, parafrase, penambahan, penghapusan, budaya. Temuan penelitian ini dapat disimpulkan bahwa teori penerjemahan masih dibutuhkan atau bahkan sangat penting dalam proses penerjemahan untuk menghasilkan terjemahan yang baik. Teori, metode, dan prosedur penerjemahan yang tepat dapat mengatasi masalah penerjemahan.
\end{abstract}

Kata kunci: anotasi, leksikon, struktur gramatikal, situasi komunikasi, dan konteks budaya.

\begin{abstract}
This research is about annotated translation with the object a novel entitled The Great Patriotic War of the Soviet Union written by Joseph Stalin. The problems of this research are: (1) What are the difficulties encountered by the researcher in translating the source text? and (2) How are those difficulties solved in the translation? The aims of this research are: (1) To identify the difficulties encountered by the translator in translating the source text; and (2) How the difficulties are solved which include strategies in translating the source text. In conducting this annotated translation, the researcher employed introspective and retrospective methods. The researcher analyzed 25 annotations of problems out of 100 items of data related to lexicon, grammatical structure, communication situation, and cultural context, and revealed that there were 17 lexicons, 7 grammatical structures, 1 communication situation. Those difficulties which, at the same time, had become problems
\end{abstract}


were analysed to attain solutions in accordance with the relevant translation strategies and translation theories, namely: descriptive translation, naturalization, paraphrasing, addition, deletion, cultural equivalent. The finding of this research can be concluded that translation theories are still needed or even they are very important in the process of translation to produce a good translation. Appropriate translation theories, methods, and procedures can overcome translation problems.

Keywords: annotation, lexicon, grammatical structure, communication situation, and cultural context.

\section{INTRODUCTION}

\section{Background of The Research}

In this part of the study the researcher is going to describe the justification of the research, relevant researches done, position of the research, and significance of the research done based on a novel of management entitled The Great Patriotic War of the Soviet Union written by Joseph Stalin (1970).

\section{Justification of The Research}

This researcher takes translation from English into Indonesian because Indonesian language is mostly known by the researcher as Indonesian language is his native language. This study is chosen by the researcher in order to increase his knowledge and widen his experience in translation which is in line with what he has learned during the two-year course. This study is very important for the researcher who is also the translator, as annotated translation applies in practical sense the theories namely: the theories of translation, theories of shift, theories of equivalence, theories of modulation, theories of over translation, theories of under translation that the researcher has studied in class during the two-year course, and to detect the problems emerging during the process of translation. The problems encountered will then be analyzed and given plausible reasons.

\section{Position of The Research}

Although a number of studies on annotated translation have been done with various source of language texts, titles, and findings, the previous studies have different sources of language texts and different categorization in their findings. Most of the previous researchers used linguistic approach and categorized their finding mostly into: words, phrases, clauses, sentences and idioms. The present study, however, attempts to analyze an annotated translation on a novel entitled The Great Patriotic War of the Soviet Union written by Joseph Stalin, and uses translation approach to categorize his findings, i.e. into four categories: lexicon, grammatical structure, communication situation, and cultural context, in accordance with Larson (2004) and Said (2009).

The similarities of the previous studies and the present study are that the previous and present studies are related to annotated translation using introspective and retrospective methods to solve the problems encountered in the process of translation. Based on the above explanation, the position of the research can be 
concluded as follows: 1) topic of studies: similar, namely annotated translation, 2) source language text: different, 3) method, to some extent is the same: introspective and introspective, but different in terms of categorization. 4) Finding: different.

\section{Significance of The Research}

The researcher expects that the result of this research can be used as an input for students of translation and translators in general, in terms of practical contribution namely how to solve difficulties during the process of translation; and in terms of theoretical review whether the theories used in solving problems are still relevant or not.

\section{Statement of The Problem}

The translator and/or the researcher encountered many difficulties during the process of translation especially in the form of cultural aspects of the source text, for example, a word 'unnecessarily....' literary means "tidak perlu/tidak penting". If it is translated literary, it will not be clear enough for the receptor language readers to understand it. So, the word "...unnecessarily ... " was translated into a phrase "... pada hal-hal yang tidak penting" to make it clearer for the receptor language readers. This difficulty became the problem for the translator/ researcher himself, which in turn it had become a research problem. Therefore, it is a requirement for the translator/researcher to have textual, cultural and understanding of both the source language and target language text. In solving this problem he referred to the translation strategies and translation theories.

At last, the problem of this research were formulated as follows:

1. What were the difficulties encountered by the researcher during the process of translation?

2. How were those difficulties solved?

\section{Purpose of The Research}

Based on the justification of the research mentioned above which was finding out difficulties in the aspects of languages namely lexicon, grammatical structure, communication situation, and cultural context, the purpose of this research is to attain factual information concerning the problems faced by the researcher/translator during the process of translation and how the problems are solved plausibly in the course of translating the source text.

\section{Scope of The Research}

The researcher was only translating 14.645 (fourteen thousand six hundred forty five) words of source language text (English), into the target language text (Indonesian), and at the same time investigating and analyzing the problems found during the process of translating based on the theories such as: theories of translation, theories of shift, theories of equivalence, theories of over translation, theories of under translation etc. The source language text was taken from a novel entitled The Great Patriotic War of the Soviet Union written by Joseph Stalin, 


\section{THEORETICAL REVIEW \\ Definition of Translation}

There are many books about theories of translation written by many experts and almost all of the experts defined translations differently. According to Catford (1965) in his book, 'A Linguistic Theory of Translation', translation is an operation performed on language: a process of substituting a text in one language for a text in another, therefore, any theory of translation must draw upon a theory of language - a general linguistic theory (p.1). In the same book Catford (1965) clearly defined translation as the replacement of textual material in one language (SL) by equivalent textual material in another language (TL) (p. 20).

Nida and Taber (1982) in their book, 'The Theory and Practice of Translation', mentioned that translating consists of reproducing in the receptor language the closest natural equivalent of the source language message, first in terms of meaning and secondly in terms of style (p. 12). Further Nida and Taber (1982) mentioned "If we look at translation in terms of the receptors, rather than in terms of their respective forms, then we introduce another point of view; the intelligibility of the translation. Such intelligibility is not, however, to be measured merely in terms of whether the words are understandable and the sentences grammatically constructed, but in terms of the total impact the message has on the one who received it". (p.22)

According to Larson (1984), translation is classified into two main types: (a) Form-based translation: attempts to follow the form of source language and is known as literal translation, and (b) Meaning-based translation: makes every effort to communicate the meaning of the source language text in the natural forms of the receptor language. Such translation is called idiomatic translation (p.15). Larson also says that idiomatic translations use natural forms of the receptor language

both in the grammatical constructions and in the choices of lexical terms. A truly idiomatic translation does not sound like a translation. It sounds like it was written originally in the receptor language (p.16).

Source Language

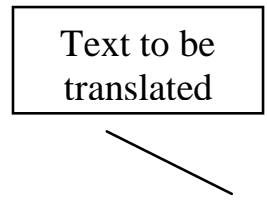

Discover the meaning
Receptor Language

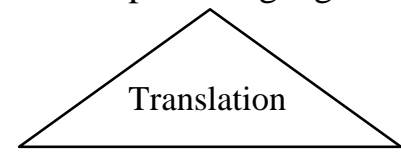

Re-express the meaning

\section{Meaning}

Figure 1. Larson's diagram on the process of translation (p.16)

Furthermore, Said (2009) in his book, 'Penerjemahan Dinamis', showed a diagram on the process of translation as follows: 


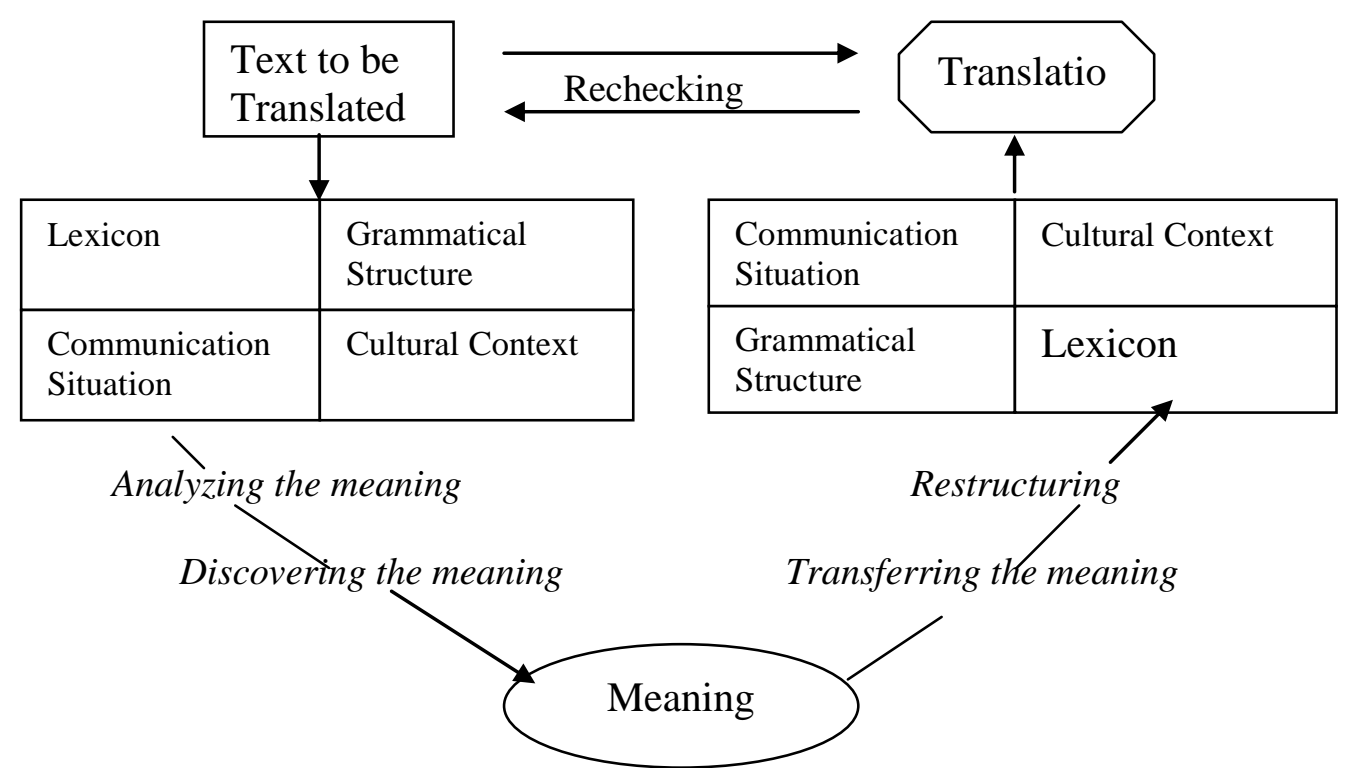

Figure .2, Said's diagram on the process of translation adapted from Larson's

\section{Annotated Translation}

According to Williams and Chesterman (2002) annotated translations or translation with commentary is a form of introspective and retrospective research where you yourself translate a text and, at the same time, write a commentary on your own translation process. This commentary will include some discussion of the translation assignment, an analysis of aspects of the source text and a reasoned justification of the kinds of solutions you arrived at for particular kinds of translation problems. One value of such research lies in the contribution that increased selfawareness can make to translation quality. (p. 7-8). According to Webster's New World Dictionary (1994), introspective means looking into one's own mind, feeling, etc; observation and analysis of oneself (p.709), while retrospective means looking back on or directed to the past, past events, etc. (p.1147).

\section{Communicative Translation}

Communicative translation is a translation which attempts to render the exact contextual meaning of the original text in such way that both content and language are acceptable and comprehensible by the readership without caring about the different structure of source and target text. Newmark (1986) mentioned that "Generally, a communicative translation is likely to be smoother, simpler, clearer, more direct, more conventional, conforming to a particular register of language, tending to under-translate, i.e. to use more generic, hold-all terms in difficult passages"

Newmark (1988) suggests that there are some types of translation method which can be used. One of them is Communicative Translation, i. e. the translation which attempts to render the exact contextual meaning of the original in such way 
that both content and language are accepted and comprehensible by the readership (p.47).

\section{Naturalization}

Naturalizing means to translate a source text into a target text in such a way that the translation becomes natural, intelligible, and makes the target readers do not know that it is a translation. Newmark (1986) mentioned that "Normally, the translator should write within his own idiolect or his conception of the source language text author's always provided the text appears to be written naturally. The translator must not use a word or phrase that sounds intuitively unnatural or artificial to him".

\section{Translation by Addition and Omission}

To make a good, natural, and intelligible translation, it is common for a translator to add or to delete the source language text in the target language text. Regarding the adding and deleting information: Nida and Taber (1982) uses the term 'expansion and reduction'; Newmark (1986) calls it 'over translation and under translation'; Duff (1991) uses the term 'too many words and too few words' (padding and gutting). Other experts use different terms, although they are talking about a similar topic.

Nida and Taber (1982) mentioned on expansion that ... there is a tendency for all good translations to be somewhat longer than the originals. This does not mean, of course, that all long translations are necessarily good. It only means that in the process of transfer from one linguistic and cultural structure to another, it is almost inevitable that the resulting translation will turn out to be longer. (p. 163)

Newmark (1986) on over translation, said that a semantic translation tends to be more complex, more awkward, more detailed, more concentrated, and pursues the thought-processes rather than the intention of the transmitter. It tends to overtranslate, to be more specific than the original, to include more meaning in its search for one nuance of meaning. (p. 39).

Newmark (1986) on under translation, mentioned that "Generally, a communicative translation is likely to be smoother, simpler, clearer, more direct, more conventional, conforming to a particular register of language, tending to under-translate, i.e. to use more generic, hold-all terms in difficult passages" (p. 39).

Whereas Alan Duff (1984) on padding mentioned that "... a translation may be longer than the original ... " And on gutting Alan Duff (1984) said, "... a translation may be shorter than the original ...".p. 22)

Deletion means the omission of the source text without translating it. It is in accordance with Peter Newmark (1988), who mentioned that deletion means omit, don't translate. (p. 283). It is also supported by Said (1994) who mentioned that deletion is omitting redundant stretches of language in non-authoritative texts, especially metaphors and intensifiers.(p. 28). 


\section{Translation Strategies}

Chesterman 's classification of translation strategies, as cited in Gabr, 2000, comprises three primary groups: (1) mainly syntactic / grammatical, (2) mainly semantic, and (3) mainly pragmatic translation strategies, and Hatim (2001), in his book 'Teaching and Researching Translation' has added the forth primary group of translation strategies with 'Emphasis on Stylistic Appropriateness', (p. 24-25, $70,101-108)$. Details of the four translation strategies are as follows:

\section{Syntactic Strategies}

Syntactic strategies have effects on the form of the text, that is, looked at from the point of view of comparing the ST and the TT Include in the Syntactic Strategies are: shifting the word-class, changing the phrase, clause or sentence structure, and changing cohesion.

\section{Semantic Strategies}

Include in the semantic strategy are the change of hyponyms into superordinates, altering the level of abstraction, redistributing the information over more or fewer elements;

\section{Pragmatic Strategies}

Include in the pragmatic strategies are: naturalizing, altering the level of explicitness, adding or omitting information.

\section{Emphasis on Stylistic Appropriateness}

Emphasized are features such as:the choice of oral or written mode, the role of sociolinguistic and situational factors, selection of appropriate genre and type of discourse, appropriate language varieties or style, and choice of formal features and lexical items.

\section{Principles of Translation}

Alan Duff (1981 p.10-11), mentioned in his book 'Translation, Resource Books for Teachers', as adopted from Frederick Fuller: The Translator's Handbook, there are six principles of translation namely:

\section{Meaning}

"The translation should reflect accurately the meaning of the original text. Nothing should be arbitrarily added or removed, though occasionally part of the meaning can be transposed".

\section{Form}

"The ordering of words and ideas in the translation should match the original as closely as possible. (This is particularly important in translating legal documents, guarantees, contract, etc.) But differences of language structure often require changes in the form and order of words." 


\section{Register}

"Languages often differ greatly in their levels of formality in a given context. To resolve these differences, the translator must distinguish between formal or fixed expressions and personal expressions".

\section{Source Language Influence}

"One of the most frequent criticisms of translation is that 'it doesn't sound natural'. This is because the translator's thoughts and choice of words are too strongly moulded by the original text. A good way of shaking off the source language (SL) influence is to set aside and translate a few sentences aloud, from memory. This will suggest natural patterns of thought in the first language (L1), which may not come to mind when the eyes is fixed on the SL text".

\section{Style and Clarity}

"The translator should not change the style of the original. But if the text is sloppily written, or full of tedious repetitions, the translator may, for the reader's sake, correct the defects".

\section{Idiom}

"Idiomatic expressions are notoriously untranslatable. These include similes, metaphors, proverbs and sayings (as good as gold), jargon, slang, and colloquialisms (user-friendly, the Big Apple, yuppie, etc), and (in English) phrasal verb." But if the idiom cannot be directly translated, try any of the following:

\section{RESEARCH METHOD}

The method of this research are introspective and retrospective research. Introspective research is a research in which the researcher investigates his own thought and feeling to get solutions, whereas retrospective research is a research where the researcher contemplates the theories and strategies used in the process of translation. The researcher himself translates the text and, at the same time, comments on his own translation process, why he comes to such a translation. Include in this method are research design, source of data, procedures of research, collection of the data, analysis of the data.

\section{Research Design}

This research employed an annotated translation. Annotated translation in this research means a translation with a commentary where the researcher himself translate a text and, at the same time, write a commentary on his own translation process. It is in line with the definition of Williams and Chesterman (2002), who mentioned as follows: "Annotated translations or translation with commentary is a form of introspective and retrospective research where the translator himself translates a text and, at the same time, writes a commentary on his/her own translation process. This commentary includes some discussions of the translation assignment, an analysis of aspects of the source text and a reasoned justification of the kinds of solutions he/she arrives at for particular kinds of translation problems. 
One value of such research lies in the contribution that increased self-awareness that can make to translation quality". (p. 7-8)

\section{Source of Data}

A book entitled 'Management Worldwide: The Impact of Societal Culture on Organizations around the Globe written by David J. Hickson and Derek S. Pugh (1995)'.

\section{Procedures of The Research}

The research procedures are as follows:

a. The source text is read thoroughly in order to get a full understanding of the content.

b. The researcher translates the source English text into Indonesian language independently.

c. The researcher, at the same time, marks down the words/ phrases/ clauses/ sentences or any other language components that has become a problem in the translating process.

d. During the course of translating the text, the researcher regularly consults with his advisor to discuss about problems he encounters.

e. The problems found during the process of translation are taken by the researcher, only the most crucial ones due to the limited time allotted.

f. These problematic items are analyzed by the researcher and then the researcher himself gives plausible reasons in solving the problems.

\section{Collection of The Data}

During the process of translating the source English text into Indonesian text, the translator/researcher collects the data which, according to the researcher, has become a problem in the translating process. The collected data are 111 items in number. Of 111 items of data collected, 35 items of data are the most difficult ones to be translated. That is why the translator/researcher annotated only these 35 items of data. Another reason is that the time alloted to the researcher cannot cover all the 111 data to be annotated.

\section{Analysis Of The Data}

The data that have been collected were categorized according to Larson (1984) that problems that may be encountered by the translator consist of four elements, i.e. lexicons, grammatical structures, communication situations, and cultural contexts. (p.3) Lexical elements were categorized into five sub-categories namely: single word, phrases, collocations, registers, and idiomatic expressions. Grammatical structure elements were categorized into clauses and sentences. Communication situation element was not found problematic in the process of translation. Cultural context elements were categorized into five categories as mentioned in Newmark (1988) adapting Nida: (1) Ecology; (2) Material culture (artefacts); (3) Social culture; (4) Organizations, customs, activities, procedures, concepts; (5) Gestures and habits. 


\section{Annotations}

Since this research uses translation approach to categorize his findings, i.e. into four categories: lexicon, grammatical structure, communication situation, and cultural context, and below are some of annotations of each category:

\section{Annotation of Lexical Items}

Include in the annotation of lexical items are annotation of word, phrase, collocation, register and idiomatic expression.

\section{a. Word}

\begin{tabular}{|l|l|l|}
\hline Data & Source Language Text & Target Language Text \\
\hline 9 & $\begin{array}{l}\text { There was no need to divide the } \\
\text { responsibility, no need to involve } \\
\text { his colleagues unnecessarily. }\end{array}$ & $\begin{array}{l}\text { Tidak perlu membagi tanggung } \\
\text { jawab, tidak perlu melibatkan rekan- } \\
\text { rekannya pada hal-hal yang tidak } \\
\text { penting }\end{array}$ \\
\hline
\end{tabular}

Analysis:

The word “...unnecessarily ...” literary means "tidak perlu/tidak penting”. If it is translated literary, it will not be clear enough for the receptor language readers to understand it. So, the word "...unnecessarily ... " was translated into a phrase "... pada hal-hal yang tidak penting" to make it clearer for the receptor language readers.

Translation Strategy:

The strategy used in translating the word "unnecessarily" into a phrase "pada hal-hal yang tidak penting" is Pragmatic Strategy: adding information. The information of "pada hal-hal yang" was added in the target language text in order to make it easier for the receptor language readers to understand it or to make it comprehensible.

Translation Theories:

1. Nida and Taber (1982) mentioned on expansion as follows: ...there is a tendency for all good translations to be somewhat longer than the originals. This does not mean, of course, that all long translations are necessarily good. It only means that in the process of transfer from one linguistic and cultural structure to another, it is almost inevitable that the resulting translation will turn out to be longer. (p. 163).

2. Munday (2001) citing Baker 1992) mentioned that pragmatics is the study of language in use. It is the study of meaning, not as generated by the linguistics system but as conveyed and manipulated by participants in a communicative situation. (p. 97). 


\section{b. Phrase}

\begin{tabular}{|c|l|l|}
\hline Data & Source Language Text & Target Language Text \\
\hline 21 & $\begin{array}{l}\text { The back wall transformed from a } \\
\text { solid mass to } \text { a rushing dust cloud }\end{array}$ & $\begin{array}{l}\text { Dinding belakang berubah dari } \\
\text { tembok yang kokoh menjadi } \\
\text { kepulan debu tebal. }\end{array}$ \\
\hline
\end{tabular}

Analysis:

The phrase "... a rushing dust cloud" was translated into "... kepulan debu tebal'. The word 'rushing' or its base 'rush', according to The Contemporary English - Indonesian Dictionary, means 'kesibukan/bergegas/buru-buru'. Based on the above meanings, the closest meaning of 'a rushing dust cloud' should be 'kesibukan awan debu' which is very awkward. The best translation of a phrase "... a rushing dust cloud" according to the researcher was "... kepulan debu tebal", to make it natural, understandable, comprehensible by the target readers and relevant to the context of the sentence.

\section{Translation Strategy:}

The strategy used in translating the phrase is Pragmatic Strategy namely Naturalizing. The phrase 'a rushing dust cloud' was translated into 'kepulan debu tebal' to make it natural and in accordance with context. Using pragmatic translation means utilizing words that are familiar with the target readers.

Translation Theories:

The underpinning theories behind the strategy are as follows:

1. Newmark (1988) mentioned that 'pragmatic' may mean 'advocating behaviour that is dictated more by practical consequences than by theory or dogma', in which case we could be discussing practical translation, translation which successfully its purpose; such translation is a desirable aim provided that the purpose is clear. (p.116).

2. Munday (2001) citing Baker 1992) mentioned that pragmatic is the study of language in use. It is the study of meaning, not as generated by the linguistics system but as conveyed and manipulated by participants in a communicative situation. (p. 97).

\section{c. Collocation}

\begin{tabular}{|c|l|l|}
\hline Data & Source Language Text & Target Language Text \\
\hline 20 & $\begin{array}{l}\text { Stained glass shot out from all } \\
\text { around the church, every window } \\
\text { shattering simultaneously-the air } \\
\text { filling with colored fragments }\end{array}$ & $\begin{array}{l}\text { Pecahan kaca } \text { berhamburan keluar } \\
\text { dari sekeliling gereja, semua } \\
\text { jendela hancur berkeping-keping } \\
\text { secara bersamaan, udara penuh } \\
\text { dengan pecahan berwarna-warni. }\end{array}$ \\
\hline
\end{tabular}


Analysis:

The phrase which is also a collocation 'shot out' was translated into a clause 'berhamburan keluar'. Both source language text and target language text are metaphoric expressions as if the 'stained glass' mentioned shot out by itself and so do the target language text. So, the best translation for the phrase 'shot out', according to the translator is 'berhamburan keluar', the metaphoric expression was translated into metaphoric expression.

\section{Translation Strategy:}

The translation strategy used in this translation is Pragmatic strategy: Naturalizing. The clause '...shot out...' was not translated in the same form with that of source language text but in the form which is clear and natural in the target language text.

\section{Translation Theory:}

Larson (1984) stated as follows: "The goal of a translator should be to produce a receptor language text (a translation) which is idiomatic; that is, one which has the same meaning as the source language but is expressed in the natural form of the receptor language. The meaning, not the form, is retained." (p.10).

\section{d. Idiomatic Expression}

\begin{tabular}{|c|l|l|}
\hline Data & Source Language Text & Target Language Text \\
\hline 90 & $\begin{array}{l}\text { Lying in bed with no purpose } \\
\text { to his day, his mind had } \\
\text { wandered, drifting over the } \\
\text { past, remembering faces like } \\
\text { the one now stuck into this } \\
\text { book. }\end{array}$ & $\begin{array}{l}\text { Hanya berbaring di tempat tidur sia-sia, } \\
\text { akan membuat pikirannya melayang- } \\
\text { layang ke masa lalu, mengenang wajah- } \\
\text { wajah seperti orang yang tercetak dalam } \\
\text { buku ini. }\end{array}$ \\
\hline
\end{tabular}

Analysis:

The idiomatic expression 'with no purpose to his day' was not translated into 'dengan tidak berguna bagi harinya', because the translation will be very awkward, very difficult for the target readers to understand, and out of context. The idiomatic expression 'his day' according to Oxford Dictionary of Idioms is used to denote someone enjoyable activities in the day. Based on that, the researcher then translated the phrase of six words simply into one word 'sia-sia' in order to match meaning with the context of the whole sentence and the whole paragraph, and it is also easier for the target readers to understand the context.

Translation Strategy:

The strategy used in translating the idioms was 'Pragmatic Strategy: Omitting information'. The expression of six words was translated simply into one word in order to match meaning with the context of the whole sentence and the whole paragraph. 
Translation Theories:

1. Translation of the idiomatic expression mentioned above is relevant to Larson's (1984) theory who defined idiom as "a string of words whose meaning is different from the meaning conveyed by the individual words" (p. 20).

2. According to Alan Duff (1984), idiom and metaphor are similar in that both involve the figurative use of language. And, in most instances, idiom, like metaphor, has a meaning that can not be directly equated with the cumulative meaning of the words in the expression. (p.89).

3. Nida and Taber (1982) mentioned that there are quite naturally some expressions which are reduced in the process of transfer from one language to another (p. 168).

\section{e. Register}

\begin{tabular}{|l|l|l|}
\hline Data & Source Language Text & Target Language Text \\
\hline 78 & Numb, Leo wiped the blood on his & Tanpa perasaan, Leo menyeka \\
& trousers, remarking: \\
& -Before we go I'd like a moment to \\
check the church. & $\begin{array}{l}\text { darah di celananya, dan } \\
\text { berkomentar: } \\
\text { Nikolai accepted the proposal at at } \\
\text { face value. }\end{array}$ & $\begin{array}{l}\text {-Sebelum kita pergi aku ingin } \\
\text { memiksa gereja sejenak. } \\
\text { Nikolai menerima usulan itu } \\
\text { sesuai permintaan }\end{array}$ \\
\hline
\end{tabular}

Analysis:

The phrase '...face value' is a register term for value printed or depicted on a coin, banknote, postage stamp, etc., which denote their actual or intrinsic value. In this context, it has nothing to do with coin, banknote, or postage stamp so that it was impossible for the researcher to translate it into 'nilai yang tertera' as it will be very awkward, unclear, and confusing for the receptor language readers to understand it because there is no money or postage stamp mentioned in the source language text. After reviewing again and again the context of the sentence, the researcher then translated it into 'sesuai permintaan'. It is in accordance with the context of request for checking the church mentioned in the conversation in the source language text.

\section{Translation Strategy:}

The strategy used in translating this phrase was Emphasis on Stylistic Appropriateness: the role of sociolinguistic and situational factors'. In this sentence, the phrase '...face value' is a figure of speech referring to value of coins, banknotes, or postage stapms. In order to render the meaning into the target language, it was not translated into '...nilai yang tertera' but into 'sesuai permintaan' in order to match it with the context of the source language text.

Translation Theories:

1. Alan Duff (1981) It would be a mistake, I think, to assume that only the literary translator is concerned with problems of style. Whatever discipline 
he may be working in, the translator will have to consider, for instance, what public work is intended for and what degree of specialist knowledge the reader is expected to have. This means he will have to decide on register (formal - informal, official - unofficial) and to maintain this register consistently throughout. (p. 7)

2. Sofer (2004) mentioned that even the best translation is never a full and true reflection of its source, simply because no two languages in the world, not even the most closely related, are identical in their way of using words and nuances. The best one can hope for its meaning, full enough not to omit any details, no matter how seemingly significant, and elegant enough to provide at least some of the stylistic character of the original text. (p.16).

\section{Annotation of Grammatical Structures}

\section{a. Clause}

\begin{tabular}{|l|l|l|}
\hline Data & Source Language Text & Target Language Text \\
\hline 23 & $\begin{array}{l}\text { If they missed the collapse, no } \\
\text { matter what the excuse, their lives } \\
\text { would be on the line. }\end{array}$ & $\begin{array}{l}\text { Apabila mereka tidak bisa } \\
\text { mengabadikan peristiwa runtuhnya } \\
\text { gereja itu, apa pun alasannya, mereka } \\
\text { tidak akan bisa melupakan peristiwa } \\
\text { itu. }\end{array}$ \\
\hline
\end{tabular}

There is an adding of information in the translation. The clause 'If they missed the collapse,...' which is consist of only five words was translated into nine words 'Apabila mereka tidak bisa mengabadikan peristiwa runtuhnya gereja itu, ...'. The purpose of the addition is to explain about the generality namely 'the collapse' mentioned in the clause. The addition of a phrase 'tidak bisa' a word 'peristiwa' and a phrase 'gereja itu' mentioned above has made the translation an over translation. By translating in such a way, the translation then becomes natural and easier for the target readers to understand it rather than if it is translated literary into "Apabila mereka kehilangan runtuhnya, ..." which is very awkward and ununderstandable.

\section{Translation Strategies}

The strategy used in translating the phrase 'Not everyday for all managers' is syntactic strategy: adding information namely by adding a phrase 'Tentu saja' and a word 'terjadi' which makes translation an over-translation. The translator also used syntactic strategy: change of phrase structure namely by changing the phrase 'Not everyday for all managers,...' into a clause 'Tentu saja hal itu tidak terjadi pada semua manajer,...".

\section{Translation Theories}

1. Nida and Taber (1982) mention that: “. . . there is a tendency for all good translations to be somewhat longer than the originals". (p. 163) 
2. Newmark (1986) mentioned that a semantic translation tends to be more complex, more awkward, more detailed, more concentrated, and pursues the thought-processes rather than the intention of the transmitter. It tends to over-translate, to be more specific than the original, to include more meanings in its search for one nuance of meaning (p.39).

3. Catford (1965), stated, by a shift of level we mean that a SL item at one linguistic level has a TL translation equivalent at a different level.

\section{b. Sentence}

\begin{tabular}{|c|l|l|}
\hline Data & Source Language Text & Target Language Text \\
\hline 13 & $\begin{array}{l}\text { Particular attention was paid to } \\
\text { ensure they caught all five cupolas, }\end{array}$ & $\begin{array}{l}\text { Mereka memberikan perhatian } \\
\text { khusus untuk memastikan bahwa } \\
\text { and there was earnest speculation } \\
\text { as to whether the timber domes } \\
\text { would smash in the air as they } \\
\text { crashed into each other or not until } \\
\text { they hit the ground. }\end{array}$ \\
& $\begin{array}{l}\text { kubah itu, dan menduga-duga } \\
\text { apakah kubah-kubah kayu akan } \\
\text { hancur di udara atau tidak saat } \\
\text { kubah-kubah tersebut saling } \\
\text { berbenturan sebelum menyentuh } \\
\text { tanah. }\end{array}$ \\
\hline
\end{tabular}

Analysis:

The sentence in the source language text "Particular attention was paid to ..." is grammatically a passive construction, but it was not translated into the same construction. Instead, the sentence was translated into an active construction "Mereka memberikan perhatian khusus kepada ...". The passive construction was changed into an active construction in order to make it easier for the target readers to understand the context of the sentence, clearer, more natural and intelligible. Therefore, the best translation according to the researcher, was changing the construction from passive construction in the source language text (SLT) into an active construction in the target language text (TLT).

Translation Strategy:

In translating this sentence, the strategy used was structure-shifts strategy or syntactic strategy: shifting of sentence namely from passive construction into active construction. This means that the structure of the original text was changed in the translation in order to cater for the readers' understanding and to achieve the requirements of a good translation: accurate, clear, natural and intelligible.

Translation Theories:

1. The underpinning theory behind this strategy is Structure-shift. According to Catford (1965), Structure-shifts are the most frequent category shifts at all ranks in translation; they occur in phonological and graphological translation as well as in total translation. In grammar, structural shift can occur at all ranks (p.77).

2. Nida (1982) mentioned that if we look at translation in terms of the receptors, 
rather than in terms of their respective forms, then we introduce another point of view; the intelligibility of translation. Such intelligibility is not, however, to be measured merely in terms of whether the words are understandable and the sentences grammatically constructed, but in terms of total impact the message has on the one who receives it. (p.22)

\section{Annotation of Communication Situation}

\begin{tabular}{|c|l|l|}
\hline Data & Source Language Text & Target Language Text \\
\hline 70 & Axes were brought against the & Axes ditarik menjauhi pintu gereja. Leo \\
& church door. Leo saw hatred in & melihat kebencian di wajah Anisya. \\
& $\begin{array}{l}\text { Anisya's face. Nikolai pulled } \\
\text { the bag from her. }\end{array}$ & Nikolai menarik tas itu dari Anisya. \\
& -He tried to save you, & -Dia berusaha menyelamatkanmu, \\
ungrateful bitch. & perempuan jalang yang tidak tahu \\
berterima kasih.
\end{tabular}

Analysis:

The phrase "...ungrateful bitch" which is spoken in an angry state, literary means "perempuan jalang tidak berterima kasih". If it is translated literary, it will not be clear enough for the receptor language readers to understand it. So, the phrase "...ungrateful bitch" which is only consist of two words was translated into a phrase of seven words "...perempuan jalang yang tidak tahu berterima kasih" to make it clearer for the receptor language readers.

Translation Strategy:

The strategy used in translating the phrase "...ungrateful bitch" into a longer phrase “... perempuan jalang yang tidak tahu berterima kasih” is Pragmatic Strategy: adding information. The information of 'yang' and 'tahu' was added in the target language text in order to make it easier for the receptor language readers to understand it or to make it comprehensible.

Translation Theories:

1. Nida and Taber (1982) mentioned on expansion as follows: ...there is a tendency for all good translations to be somewhat longer than the originals. This does not mean, of course, that all long translations are necessarily good. It only means that in the process of transfer from one linguistic and cultural structure to another, it is almost inevitable that the resulting translation will turn out to be longer. (p. 163).

2. Munday (2001) citing Baker 1992) mentioned that pragmatics is the study of language in use. It is the study of meaning, not as generated by the linguistics system but as conveyed and manipulated by participants in a communicative situation. (p. 97). 


\section{RESULT AND DISCUSSION}

As much as 100 items of difficulties have been collected and used as data, but the researcher has only taken 25 items of the data which are the most difficult ones to be annotated. Those 25 items of data were grouped into four categories namely: lexicon, and grammatical structure, and found among them: 17 items of lexicon problems consisting of 5 items of single words, 7 items of phrases, 3 items of collocations, and 2 items of idiomatic expressions; 7 items of grammatical structure problems consisting of 4 items of clauses and 3 items of sentences; and 1 item of communication situation problem. No cultural context problem was found in this research.

In order to make it clearer for the readers to see the result of this research, below are the table of categories of the data, completed with the numbers of annotated items of each category, and the percentage of each category as shown on tables and figures shown below.

Table 1. Categories of the Annotated Items

\begin{tabular}{|l|l|l|l|}
\hline No. & Categories & $\begin{array}{l}\text { Numbers of } \\
\text { Annotated Items }\end{array}$ & Percentage (\%) \\
\hline 1. & Lexicon & 17 & 68 \\
\hline 2. & Grammatical Structure & 7 & 28 \\
\hline 3. & $\begin{array}{l}\text { Communication } \\
\text { Situation }\end{array}$ & 1 & 4 \\
\hline \multicolumn{2}{|l|}{ Total Annotations } & 25 & $100 \%$ \\
\hline
\end{tabular}

Table 2. Lexicon

\begin{tabular}{|l|l|l|l|}
\hline No. & Lexicon & $\begin{array}{l}\text { Numbers of } \\
\text { Annotated Items }\end{array}$ & Percentage (\%) \\
\hline 1 & Word & 5 & 29 \\
\hline 3 & Phrase & 7 & 41 \\
\hline 4 & Collocation & 3 & 18 \\
\hline 5 & Idiomatic Expression & 2 & 12 \\
\hline Total & Annotations & 17 & $100 \%$ \\
\hline
\end{tabular}

Table 3. Grammatical Structure

\begin{tabular}{|l|l|l|l|}
\hline No. & Grammatical Structure & $\begin{array}{l}\text { Numbers of } \\
\text { Annotated Items }\end{array}$ & Percentage (\%) \\
\hline 2 & Clause & 4 & 57 \\
\hline 3 & Sentence & 3 & 43 \\
\hline \multicolumn{2}{|l|}{ Total Annotations } & 7 & $100 \%$ \\
\hline
\end{tabular}


Table 4. Communication Situation and Cultural Context

\begin{tabular}{|l|l|l|l|}
\hline No. & $\begin{array}{l}\text { Communication Situation } \\
\text { and Cultural Context }\end{array}$ & $\begin{array}{l}\text { Numbers of } \\
\text { Annotated Items }\end{array}$ & Percentage (\%) \\
\hline 1 & Communication Situation & 1 & 100 \\
\hline 2 & Cultural Context & 0 & 0 \\
\hline \multicolumn{2}{|l|}{ Total Annotations } & 1 & $100 \%$ \\
\hline
\end{tabular}

\section{CONCLUSION AND RECOMMENDATION}

\section{Conclusion}

In this research there were four aspects annotated, i.e. lexical items, grammatical structure, communication situation, and cultural context. Lexical items consist of words, phrases, collocations, idiomatic expressions, and register; grammatical structure consist of clauses and sentence. Only one communication situation was found and no cultural context was found in this research.

\section{Recommendation/Suggestion}

The restrictiveness of time allotted to the translator/researcher, has made him unable to complete translating the novel The Great Patriotic War of the Soviet Union written by Joseph Stalin nor annotating all the problems found during the process of translation. And, the four categories of problems namely the problems of lexicon, grammatical structure, communication situation and cultural context which were supposed to be encountered in this research, only three categories namely lexicon, grammatical structure and communication situation problems were found. Due to the above, the translator/ researcher highly recommends that other translators/ researchers who are going to conduct annotated translation research, to continue their research based on the book in order to encounter the cultural context problems. By doing research on this book, the translator/ researcher will be able to produce a much better translation on this field, and as a result, it will be easier for the target readers to understand content of the book.

\section{REFERENCE}

Baker, Mona. (1997). In Other Words: A Coursebook on Translation. London: Routledge.

Catford, J. C. (1965). A Linguistic Theory of Translation. London: Oxford University Press.

Duff, Alan. (1981). Translation. Oxford: Pergamon Press.

Duff, Alan (1984). The Third Language: Recurrent Problems of Translation into English. Oxford: Pergamon Press. 
Hatim, Basil. (2001). Teaching and Researching Translation. Harlow, England: Pearson Education Limited.

Larson, Mildred L. (1984). Meaning-Based Translation: A Guide to CrossLanguage Equivalence. Maryland: University Press of America.

Munday, Jeremy. (2001). Introducing Translation Studies: Theories and Application. London: Routledge.

Newmark, Peter. (1986). Approaches to Translation. Oxford: Pergamon Press.

Newmark, Peter. (1988). A Textbook of Translation. New York: Prentice Hall.

Nida, Eugene A. and Taber, Charles R. (1969). The Theory and Practice of Translation. Leiden: United Bible Societies.

Said, Mashadi. (1994). Socio-cultural Problem in the Translation of Indonesian Poems into English (a case study on 'On Foreign Shores). Unpublished Thesis, Post Graduate Program Universitas Negeri Malang.

Said, Mashadi. (2009). Penerjemahan Dinamis. Ciputat, Tangerang Selatan: Churia Press.

Sofer, Morry. (2004). The Translator's Handbook. Maryland: Schreiber Publishing, Inc.

Stalin, Joseph. (1970). The Great Patriotic War of the Soviet Union. Moscow: Greenwood Press.

Williams, Jenny \& Andrew Chesterman. (2002). The Map: A Beginner's Guide to Doing Research in Translation Studies. Manchester: St. Jerome Publishing. 